\title{
Platinum and platinoids in the Bolotisty gold-placer deposit (Khabarovsky Krai, Russia)
}

\author{
Natalya Lavrik $^{1 *}$, Valentina Stepanova ${ }^{1}$ and Alexandra Lavrik ${ }^{1}$ \\ ${ }^{1}$ Mining Institute FEB RAS, 51 Turgenev st., Khabarovsk, 680000, Russia
}

\begin{abstract}
Annotation. The article shows the results of studies the platinum mineralization (within the framework of studying the complexity of deposits) in the waste of heavy concentrate in the southeastern flank of the Bolotisty gold-placer deposit, which the located in the Khabarovsky Krai (Russia). The deposit is localized in the "erosion window" among the covers of Miocene basalts and Eocene andesites, where Cretaceous sedimentary, tuffaceous-sedimentary rocks of the basement of the volcano structure, broken through by an Eocene intrusive body of intermediate and basic composition, come to the surface. An abbreviated mineralogical analysis for monofraction of precious metals was carried out for a concentrate fraction weighing $1.813 \mathrm{~kg}$ with a grain size of $-3.0+0.1 \mathrm{~mm}$. Gold and platinum were found $-1.38 \mathrm{mg}$ and $1.08 \mathrm{mg}$. Platinum has an iron impurity up to $3-5 \% \mathrm{Fe}$ and $\mathrm{Cu}$, $\mathrm{Ir}$, $\mathrm{Rh}$ impurities are variable. There are plate-like inclusions of native osmium with an admixture of ruthenium in $43 \%$ of the studied platinum grains. There are single inclusions of ehrlichmanite. A large amount of high-temperature dipyramidal quartz, along with magnetite, chromite, tourmaline and other minerals is a characteristic feature of the concentrate and platinum grains of this area.
\end{abstract}

\section{Introduction}

Not only ore complex deposits of various genesis, containing platinum (for example, ironmanganese Poperechnoe deposit, gold-copper-porphyry Malmyzh deposit [1, 2]), but also gold-placer deposits, in which platinoids are found, according to the results of the recent decades scientific research, and also geological and mining operations in the south of the Far East. In particular, this article presents data on the commensurate content of platinum and gold in the material of the gravity concentration tailings in the southeastern flank of the Bolotisty placer deposit.

The economic expediency and the need to extract associated components should be justified economically and technologically. At the initial stage, there is a need to investigate noble metal mineralization in complex deposits. Despite the relatively low annual production, the prospects for the platinoids of the Far East are estimated to be quite high. First of all, the attention of researchers is attracted both by the wide area development of platinum-metal mineralization and the variety of types of their manifestations [4].

\footnotetext{
*Corresponding author: lavrik@igd.khv.ru
} 
The overview of ore and potentially ore platinum mineralization and gold placer with platinoids give in the work of V. G. Moiseenko et al. [4]. Platinum mineralization of the Upper Amur province is concentrated in a sub-latitudinal strike. In this area, there are 3 potential platinum-bearing metallogenic zones: Dambukino-Tyndinskaya, DzhagdySelemdzhinskaya and Severo-Bureinskaya. Within the zones, there are numerous finds of PGE minerals in gold placers. Sperrylite and platinum predominate among the PGE minerals, less often ferroplatinum and iridosmin, iridous platinum and very rarely osmous iridium. Often, the platinoid content in these placers was comparable to that of Au.

The Stanovaya and Maimakan platinum-bearing zones are known in the Priokhotsk province. Grains of the platinoids, chromites and gold, osmous iridium and ferroplatinum were washed in the gold-bearing placers of the Stanovaya zone according to G.S. Mirzekhanov. From the minerals of the platinum group: stibiopalladinite form, sulfideplatinum and platinum-ferruginous forms, cooperite, predominate in the gold-bearing placers of the Maimakan zone.

Since 1897, the Fadeevsky site in the Primorsky province has been known as a goldplacer area. Platinoids were found all over the placers of the Fadeevka brook and the Zolotoy spring. Their approximate content was estimated by the prospectors as $1:(50-70)$ to the amount of gold. There were of the platinum minerals: isoferroplatinum, tetraferroplatinum, osmirides with ruthenium, sulfides, platinoid arsenides, and varieties with antimony impurities, minerals of the vysotskite-braggite series.

The Ussuri platinum-bearing zone extends in the NE direction from the city of Nakhodka through the upper reaches of the Ussuri to the upper reaches of the Anyui and Gur rivers. A rich gold-bearing placer with large high-grade (average fineness 948) gold is mined in the northern part of the zone at the Bolotisty site located in the upper reaches of the Khor river. Quartz and quartz-tourmaline stockworks in the endo- and exocontacts of the Paleogene massif of dioritoids and gabbroids, breaking through sedimentary rocks of the Lower Cretaceous, are a source of gold. Complex platinoids containing platinum and palladium were found in heavy concentrates from crusts of silicified siltstones and sandstones of the exocontact zone ( 8 samples). The rocks contain thin veinlets of fine crystalline quartz $[5,6]$.

\section{Factual material and research methods}

Samples from waste of heavy concentrate at the confluence site of the Bolotisty - Yakchi streams from the southeastern flanks (least studied) of the Bolotisty gold-place deposit of the Khabarovsky Krai were studied at the Mining Institute FEB RAS in accordance with the direction of studies of the complexity of deposits for platinoids. Covers of Miocene basalts, Eocene andesites, basaltic andesites and their tuffs are found within the indicated rivers and Triassic - Cretaceous subvolcanic intrusions in the Central Sikhote-Alin fault zone.

\subsection{Geological characteristics of the Bolotisty deposit}

A brief geological description of the Bolotisty deposit is given according to works [7-9]. The Bolotisty ore field is part of the Pravo-Sooliysk gold-bearing ore-placer cluster, which is structurally confined to the central part of the West Sikhote-Alin volcanic zone.

The gold-bearing ore-placer cluster is located within a large, zonally constructed positive morphostructure of the central type (volcanogenic-plutonic uplift), clearly expressed in the relief, the structure of the hydraulic network and geophysical and geochemical fields. The central Sikhote-Alin structural seam (the largest deep-seated fault) 
within the area is represented by two sub-parallel faults traced along the sides of the Tormasu and Sooli rivers.

The deposit is localized in the "erosion window" among the covers of the Miocene basalts of the Kizin formation $\left(\mathrm{Ng}_{1} \mathrm{kz}\right)$ and eocene andesites, basaltic andesites of the Kuznetsov formation ( $\mathrm{Pg}_{2} \mathrm{kuz}$ ), where Berriasian-Valanginian ( $\mathrm{K}_{1}$ bv) sedimentary, basement and volcanic-sedimentary formations come to the surface erupted by an Eocene intrusive body of $1.8 \mathrm{~km}^{2}$ of complex composition (gabbro, gabbro-diabase, diabase, gabbro-diorite, diorite, quartz diorite; lumps of amphibolized pyroxenites and bodies of fine-grained melanocratic rock with a breccia structure) are singly noted. The dike complex consists from the bodies of gabbro-porphyrites, gabbro-diorite porphyrites, and granodiorites.

Siltstone strata of Berriasian age $\left(\mathrm{K}_{1} \mathrm{~b}\right)$, composed of monotone black, dark greenishgray siltstones, silty sandstones with interlayers and lenses of mudstones, polymictic sandstones, gravelites developed in the eastern part of the ore field. The sandstone strata of the Valanginian stage $\left(\mathrm{K}_{1} \mathrm{v}\right)$ conformably overlap the Berriasian deposits and are developed mainly in the western part of the ore field. It is composed of polymictic and quartz-feldspar sandstones with rare interlayers of siltstones, gravelstones, conglomerates, and consedimentary breccias. The rocks contain an admixture of fine-grained pyroclastic material (from 10 to $60 \%$ ).

Basalts are dark gray in color, massive, almond-shaped, less often spongy-porous; spherical jointing is characteristic; in phenocrysts - biotite, leucite, apatite, indicating their increased alkalinity. The pores of the basalts are partially filled with analcime and chalcedony-like quartz. Alkaline basalts of Primorye contain gold and platinoids according to the research results of V. G. Sakhno with coauthors [10].

Along the sides of the brook Vstrechny-Bolotisty, sandy loam, cementing deluvial folds of basalts is saturated with fine-crystalline transparent quartz. Crystals $1-5 \mathrm{~mm}$ in size, have a pyramidal, bipyramidal shape, rarely with elements of prisms.

Most of the rocks composing the ore field are affected by the processes of contact and hydrothermal-metasomatic changes. There are distinguished: contact hornfelses, pre-ore propylitized, argillized and tourmalinized hydrothermally altered rocks. This process is most intense in its southeastern part, in the exocontact of the gabbro-diorite intrusion.

Tourmalinites are one of the characteristic and specific features of the Bolotisty ore field. They are developed mainly in its central part. Along with massive tourmalinites, the development of tourmaline, quartz-tourmaline sulfide-quartz-tourmaline breccias composing local steeply dipping (tubular?) bodies is characteristic. Gold-ore quartztourmaline vein mineralization is genetically closely related to tourmaline and tourmaline breccias.

The peculiarities of the Bolotisty ore field and the cluster allowed researchers to assume that there is a partially eroded paleovolcanic edifice of the central type [7]. The eastern part of the volcano-plutonic structure, located in the zone of active influence of the Central Sikhote-Alin fault, is the most destroyed and eroded. The western part is the least eroded.

Large and medium-sized alluvial gold-bearing placers have been identified at the deposit in the Sredniy and Klyuchevoy streams - tributaries of the Bolotisty stream. These are placers of near drift, formed as a result of processing of gold-bearing slope material and the influx of metal from ore bodies uncovered in the raft. The distant drift placer is located downstream of the Bolotisty stream. It doesn't have direct connection with the primary source and was formed due to the transit metal [11].

Most of the ore-bearing zones are confined to faults in the northwestern and nearmeridional orientations. Gold in ore bodies is associated with quartz, sulfides of copper, arsenic, iron, antimony and bismuth tellurides. Sometimes mimetizite, antimonite are found with bismuth tellurides, in which, along with impurities of bismuth, tellurium, iron, lead, 
copper and chromium, an impurity of gold, palladium and platinum is found. In those gold samples where palladium is found, it correlates with copper, bismuth, and tellurium, which apparently indicates their paragenetic connections. [12-14].

\subsection{Research methods}

The sample (with a total weight of $13 \mathrm{~kg}$ ) was enriched by the magnetic-gravity method. A Stemi 2000 C microscope (Germany, ZEISS) was used to carry out a reduced mineralogical analysis for the main component composition. Evaluation of the heavy concentrate fraction for gold and platinum content was carried out using the method of mineralogical analysis for monofraction of precious metals. The slurry fraction for gold and platinum content was estimated using mineralogical analysis for monofraction of noble metals. The non-magnetic fraction amounted to $1 / 4$ of concentrate weight. A detailed study of the grains of valuable components was carried out on a JEOL microscope (Japan) equipped with a JCM-6000 PLUS energy-dispersive X-ray analyzer.

\section{Research results}

The bulk of the mineral composition of the concentrate is magnetite; ilmenite, pyroxenes, olivine, amphiboles, tourmaline, epidote, jarosite, limonite, and hematite are present. Zircon, corundum (sapphire), spinel, cassiterite, pyrite, scheelite, marcasite, nitrogenous carbonaceous formations, moissanite, complex intermetallic compounds are found in the concentrate.

The presence in all fractions of a large number of crystals and fragments of rock crystal and rauchtopaz is the most striking characteristic feature of the mineral composition of the concentrate. Quartz crystals are well-faceted bipyramids with a narrow prism belt. As you know, this is a high-temperature modification of quartz, crystallizing in the temperature range $575-870^{\circ} \mathrm{C}$, with free growth. Zircons are from colorless to red. The red ones are bipyramidal with a narrow belt or short prism.

As a result of the analysis of monofractions, gold $(1.38 \mathrm{mg})$ and platinum $(1.08 \mathrm{mg})$ were found. Gold is predominantly in the non-magnetic fraction, and platinum is mainly in the magnetic fraction (from the 24 discovered platinum grains, 16 are in the magnetic fraction).

The gold. Grains have: size from 0.1 to $1.0 \mathrm{~mm}$; color is bright yellow; the morphology of grains is diverse: lamellar, tapered, wire-like, small grains isometric-rounded with elements of faces, deformed crystals. The surface of the small grains is clean, shiny; large grains have a limonite jacket and greases of iron hydroxides (rust).

The composition of gold even in one grain is variable, according to the results of electron microscopic studies: gold with an admixture of silver $\rightarrow$ gold with an admixture of lead and silver $\rightarrow$ gold with an admixture of galena $\rightarrow$ electrum (Fig. 1). The inclusions of rock-forming minerals in gold grains are about $5 \%$. The presence of magnetite or hematite, substituted by hydroxides and iron ochers, is characteristic. Magnetite is singly present in the form of octahedral 20-25 $\mu \mathrm{m}$ in size. Ocher and films of iron hydroxides make up about $25 \%$ of the gold surface. Hornblende, tourmaline, and arsenopyrite are found in the inclusions. 

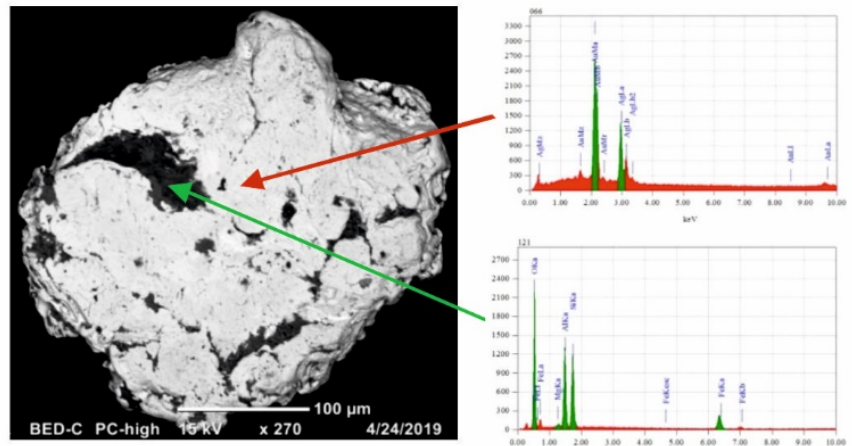

\section{Composition, $\%$}

Mass: Atomic:

$\mathrm{Au}-68.09 \mathrm{Au}-53.88$

Ag-31.91 Ag-46.12

Mass: Atomic:

$\begin{array}{ll}\mathrm{Fe}-8.07 & \mathrm{Fe}-2.86 \\ \mathrm{Si}-15.58 & \mathrm{Si}-10.98 \\ \mathrm{Al}-16.05 & \mathrm{Al}-11.77 \\ \mathrm{Mg}-0.50 & \mathrm{Mg}-0.40 \\ \mathrm{O}-59.81 & \mathrm{O}-73.99\end{array}$

Fig. 1. Gold grain of complex structure and composition. The Bolotisty placer gold deposit, the southeastern flanks of the deposit, the confluence of the Bolotisty - Yakchi streams.

The platinum. Grains have: size from 0.1 to $0.5 \mathrm{~mm}$; color light gray, gray with matte sheen. The forms of excretions are predominantly lumpy-isometric, there are cubic habit, 1 grain - bottle-shaped. The surface of all grains is rough.

Platinum grains isolated by mineralogical analysis have a complex shape, structure and composition according to the results of electron microscopic studies. The size of the studied grains is from 150 to 500 micrometers. Grains of platinum are found irregular-lumpy, irregular-prismatic, bottle-shaped (formed by intergrown prismatic, cubic and irregular crystals of platinum with an admixture of iron). In most cases, the grains are aggregates of slightly smoothed cubic crystals, prismatic, lamellar and close to spherical or globular, up to 20-30 microns in size. The presence of a large number (up to $30 \%$ of the surface) ingrowths of rock-forming minerals: hornblende, enstatite, apatite, zircon, quartz, carbonaceous and nitrogenous-carbonaceous formations, crusts and deposits of complex phosphate compounds, chromite, which fill all the depressions in the grains, is a characteristic feature grains of platinum from the Bolotisty gold-placer deposit. The size of these formations ranges is from 5-10 micrometers to 50-100 microns. They are both individual grains-crystals and nest-like clusters (Fig. 2, 3, 4).
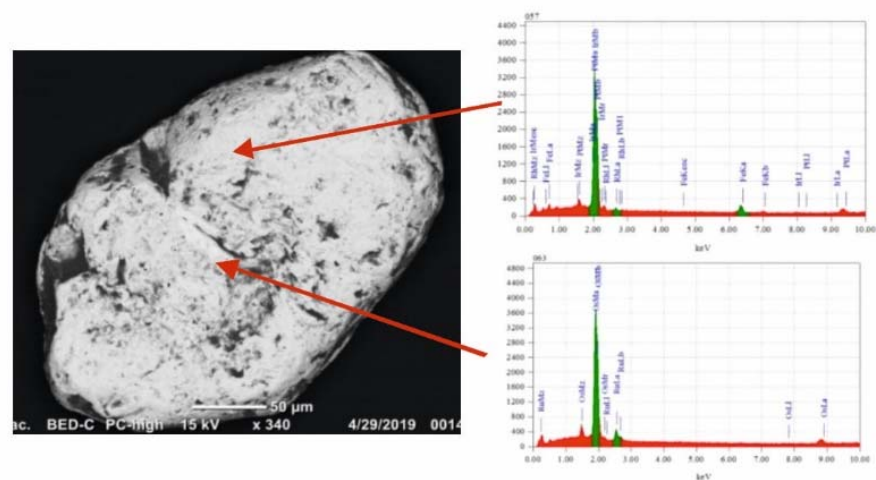

\section{Composition, \%}

Mass: Atomic:

$\mathrm{Pt}-69.71 \mathrm{Pt}-63.60$

Ir - 25.92 Ir - 24.01

$\mathrm{Fe}-3.31 \quad \mathrm{Fe}-10.55$

$\mathrm{Rh}-1.06 \mathrm{Rh}-1.84$

Mass: Atomic:

Os -90.41 Os -83.37

$\mathrm{Ru}-9.59 \mathrm{Ru}-16.63$

Fig. 2. A smoothed grain of platinum of a complex composition containing thin lamellar inclusions of native osmium with an admixture of ruthenium. 


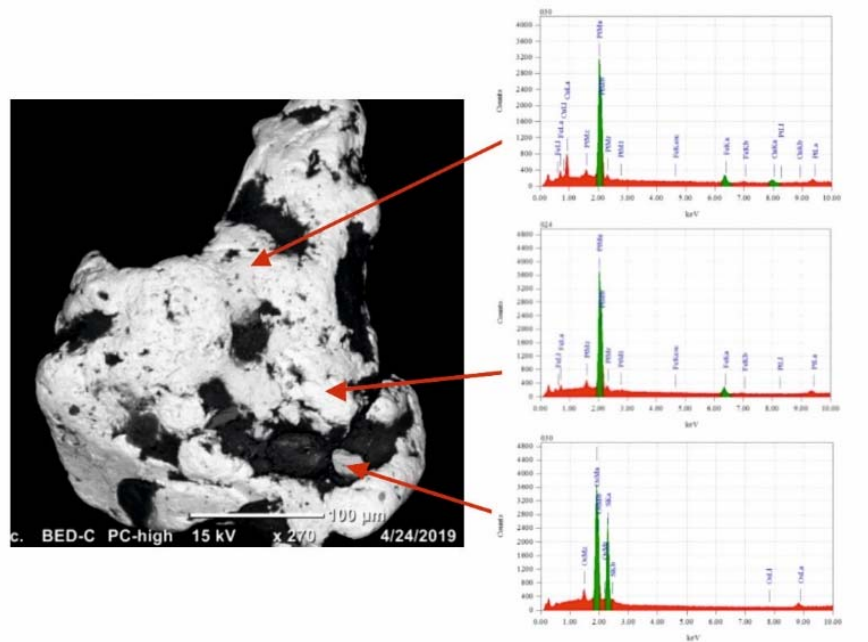

Composition, \%

Mass: Atomic:

Pt - 95.16 Pt - 85.09

$\mathrm{Fe}-4.32 \mathrm{Fe}-13.50$

$\mathrm{Cu}-0.52 \mathrm{Cu}-1.42$

Mass: Atomic:

Pt -96.40 Pt -88.45

$\mathrm{Fe}-3.60 \quad \mathrm{Fe}-11.55$

Mass: Atomic:

Os -75.31 Os -33.96

S - 24.69 S - 66.04

Fig. 3. Grain of platinum of complex shape and structure, containing ingrowths of rock-forming minerals and wedge-shaped grain of ehrlichmanite.
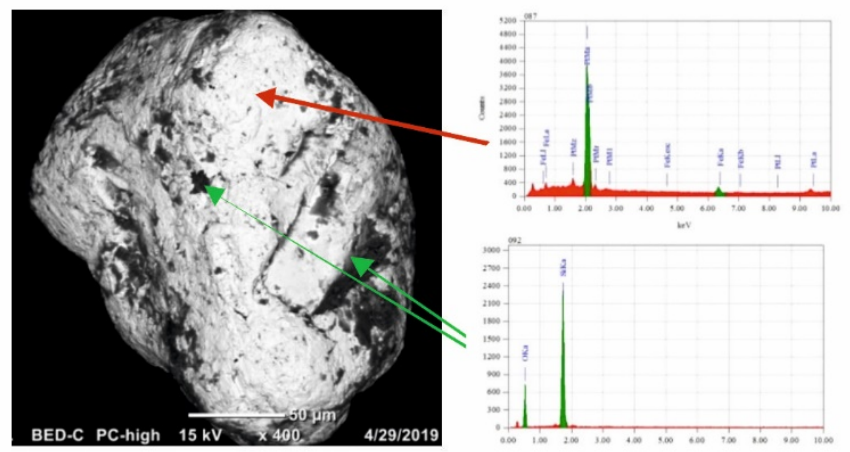

\section{Composition, $\%$}

Mass: Atomic:

Pt -97.35 Pt -91.33

$\mathrm{Fe}-2.65 \quad \mathrm{Fe}-8.67$

$\begin{array}{cr}\text { Mass: } & \text { Atomic: } \\ \text { O-52 } & \text { O }-65.54 \\ \text { Si }-48 & \text { Si }-34.46\end{array}$

Fig. 4. One of the grains of platinum containing single and nested quartz inclusions.

The composition of platinum is variable: platinum predominates with iron impurities up to $3-5 \%$, rarely up to $10 \%$ by weight, may contain copper impurities (less than $1 \%$ by weight), less often - rhodium and iridium. Thin inclusions of native osmium plates with Ru impurities up to $5.36 \%$ by weight (decomposition structures) were observed in $20 \%$ of all studied platinum grains (Fig. 2). Native osmium, in addition to ruthenium, contained an insignificant admixture of iridium only in one case. A wedge-shaped ehrlichmanite crystal $\mathrm{OsS}_{2}$ is present in one platinum grain in a nest containing rock-forming minerals (Fig. 3). There is chromite, hornblende, and tourmaline.

The presence of quartz (up to 5-10 micrometers) in phenocrysts of platinum grains is an unusual association. Separate well-faceted crystals and accumulations of quartz were noted in $43 \%$ of the studied platinum grains (Fig. 4 ).

\section{Conclusions}

The composition of the studied platinum grains is peculiar: platinum predominates with a low iron content, stable up to 3-5\%. Areas (ingrowths) with rhodium and iridium content are observed in grains variably; plates of native osmium with an admixture of ruthenium (decomposition structures) are present in $20 \%$ of platinum grains; ehrlichmanite crystals are isolated. The complex composition and structure of platinum grains, which also contain other platinoids, possibly is indicates high temperatures of their formation. The shapes of 
platinum grains - uneven, slightly smoothed cubic and prismatic crystals and their aggregates tell about a close source of drift.

The presence of well-faceted dipyramidal high-temperature quartz crystals is a characteristic feature of the concentrate. Platinum grains contain a large amount of inclusions of rock-forming minerals, and in particular - quartz.

It is noted that along the sides of the Vstrechny - Bolotisty brooks, the sandy loam cementing deluvial dumps of basalts is saturated with fine-crystalline transparent quartz, in works on the study of the Bolotisty gold placer deposit. Crystals 1-5 $\mathrm{mm}$ in size, have a pyramidal, bipyramidal shape, rarely with elements of prisms. Apparently, a similar situation is observed at the confluence of the Bolotisty - Yakchi brooks, where samples were taken for mineralogical studies.

Based on the features of the mineral composition of the gold placers of the Bolgotsky deposit, it can be assumed that there are two sources of platinum. One of them, possibly, is associated with basalt covers and loose (partly pyroclastic?) material cementing deluvial basalt heaps. The second is with ruptured ore zones containing gold, quartz, sulfides, tellurides, as well as platinum and palladium.

The ratio of gold and platinum extracted from sample of waste of heavy concentrate is approximately the same. That is, during finishing it is possible to extract additional gold and platinum, which is confirmed by the "gravitational size" of the grains and, in relation to platinum, the lumpy isometric shape of the grains with a rough surface. The platinum contains a large amount of inclusions of rock-forming minerals, which requires the development of combined technological solutions to reduce the loss of a valuable component during the enrichment of the mineral mass.

It is necessary to purposefully evaluate gold deposits for platinum and platinoids, which requires a special approach, certain skills and knowledge.

Platinum has been known in gold-placer deposits since ancient times all over the world - in Egypt, Spain, Colombia, Brazil, Finland, etc. [15, 16].

\section{References}

1.V. G. Kryukov, N. M. Litvinova, N. A. Lavrik, V. F. Stepanova, Ore mineral prossesing, 4 (370), 42-48 (2017)

2. N. Lavrik, N. Litvinova, T. Aleksandrova, V. Stepanova and A. Lavrik, Problems of Complex Development of Georesources, (2018)

3. A. P. Van-Van-E, Resource base of natural and technogenic gold-placer deposits, (2010)

4. V. G. Moiseenko, V. A. Stepanov, L. V. Airish, A. V. Melnikov, Platinum-bearing capacity of the Far East, (2004)

5. Yu. I. Bakulin, V.A. Buryak, G. S. Mirzekhanov et al., Mineral and raw materials complex of the Far East Region at the turn of the century, 178, (1999)

6. L. V. Airish, V. A. Stepanov, Pacific Geology. 21, 3, 27-39 (2002)

7. L. B. Sushkin, Endogenous mineralization in mobile belts, 176-180 (2007)

8. L. B. Sushkin, Geophysical Studies of the Urals and adjacent regions, 252-255 (2008)

9. V. M. Stepanenko, A. I. Zambrzhitskiy, V. A. Buryak, Genesis of gold deposits and methods of extraction of noble metals, 145-147 (2001)

10. V. G. Sakhno, P. P. Safronov, L. F. Simanenko, Nanogeochemistry of gold, 17-18 (2008)

11. A. A. Grebennikova, Ores and Metals, 1, 60-69 (2013)

12. V. V. Ivanov, L. G. Kolesova, A. A. Lotina, Structure, Matter, History of the Lithosphere of the Timan-North Ural segment, 110-112 (2007)

13. V. V. Ivanov, L. G. Kolesova, A. A. Lotina et al., Structure, Matter, History of the Lithosphere of the Timan-North Ural Segment, 79-81 (2009) 
14. V. V. Ivanov, L. G. Kolesova, S. O. Maksimov et al., Geological Processes in subduction, collision and slip of lithospheric plates, 353-356 (2011)

15. F. Reith, G. Nolze, R. Saliwan-Neumann, B. Etschmann, Jo. Brugger, Gondwana Research, 76, 246-259 (2019)

16. A. R. Cabral, M. Radtke, F. Munnik, B. Lehmann, R. Kwitko-Ribeiro, Chemical Geology, 281, 125-132 (2011) 